\title{
Are Palestinian SMEs Effectively Utilizing Mobile Banking?
}

\author{
Hamed M. H. Mujahed \\ Centre for Postgraduate Studies \\ (PGC), Limkokwing University of \\ Creative Technology, Malaysia.
}

\author{
Elsadig Musa Ahmed \\ Faculty of Business, Multimedia \\ University, Melaka 75450, Malaysia.
}

\author{
Siti Aida Samikon \\ Centre for Postgraduate Studies \\ (PGC) Limkokwing University of \\ Creative Technology, Malaysia.
}

\begin{abstract}
This paper investigates reason for the nonutilization of mobile banking by SMEs sectors in Palestine using a survey of 408 SMEs. The results of the study indicate that majority of Palestine SMEs are using computerized systems and utilizes basic ICT technologies, while the use of mobile banking are less than $30 \%$. However, there are key factors that inhibit these SMEs from effectively utilizing mobile banking in their various businesses. The survey reveals that understanding of mobile banking adoption is very little among the SMEs business owner's, regulatory environment, mobile banking business model offered by banks are the most prevalent factors for non-utilizations of mobile banking.
\end{abstract}

Keywords:- Mobile Banking, Palestinian SMEs, SMEs Effective, Palestine.

\section{INTRODUCTION}

In both developed and developing countries, Small and Medium Sized Enterprises (SMEs) plays an important role in the process of economic growth and industrializations (Bill \& Melinda Gates Foundation, 2017). SMEs contribute significantly to the economic development of Palestine and consider as the economy engine of the country (Mosallem, 2016), (Morrar, et, al. 2019), and it's One way of fighting unemployment and poverty, and plays an important role in the Palestinian economy development (N. Sabri, 2012). The Palestinian economy in the main aspect is consider as an emergency economy and a service economy, and the private sector is a driving force of the national economy in Palestine, and it's a tool to absorb the economic shocks to which the national economy is exposed or may be exposed. Based on the Palestinian Central Bureau of Statistics General report of residents and establishments the total number of SMEs in Palestine are 125,501 SMEs (PCBS, 2017). SMEs in Palestine plays a critical and significant role in the economic development and growth and selfsufficiency in various aspects (N. Sabri, 2012), (Ministry of National Economy, 2019), (Rasha Yousef et, al. 2019). Operational inefficiencies and highly operations costs are two important hurdles for the Palestinians SMEs to achieve scale. (Abualrob \& Kang, 2016), (PCBS, 2017), (Mohammed, et al. 2020). Also SMEs in Palestine play a significant role in boosting GDP and living standards, encouraging domestic investment, recycling national income and decreasing unemployment rates (Minstry of National Economy, etl. 2019).
Mobile banking emerged to provide a new financial services at lower costs through mobile platforms and applications. The interest over mobile banking products is becoming increasingly intense (Tiwari, et, al. 2006), $(\mathrm{H}$. Mohammadi, 2015), (Venkatesh \& Davis, 2016), (Afshan \& Sharif, 2016), (Ammar \& Ahmed, 2016), (Claire, 2016). Mobile Banking offers good opportunities to meet consumer preferences, increase loyalty, strengthen relationships and it will bring a positive impact on SMEs (Maldeni and Jayasena, 2009), (Rahman \& Ict, 2018), (Mobile Banking Study, 2013), (Muchiri, 2018), (Katua, 2014), (Mandari et al., 2019).

Mobile banking is in its early stage usage and understanding in Palestine in general and specially among the SMEs sectors, such a technology is used offered by some banks in Palestine to customers as individual users, our intention in this study to focus on the SMEs perspectives as an (organization perspectives), due to the importance of using mobile banking in the companies in Palestine to facilitate their business operations, save their time, save cost and reach to larger market areas. This study aims to investigate if mobile banking is being effectively used and utilized among SMEs in Palestine. The adoption of mobile banking in Palestine SMEs is still lower than expected, many barriers to mobile adoptions and other ICT application in SMEs have been identified in Palestine (Grossman, 2008), (Rabayah \& Qalalwi, 2011), (Abualrob \& Kang, 2016). In Palestine the understanding of mobile banking adoption is very few among the SMEs business owners (Rahman \& Ict, 2018). The Palestinian SMEs could use mobile banking in order to grow and become more innovative and improve overall operational performance (Tarutė \& Gatautis, 2014), (Rahman \& Ict, 2018).

\section{LITERATURE REVIEW}

\section{A. Significance of SMEs}

In the developing countries, SMEs plays an important role in the economic growth, the employment creation and economic development has occupied most of the discussion among academics, government, researches, government and policy makers. The SMEs play a significant role in boosting GDP and living standards, encouraging domestic investment, recycling national income and decreasing unemployment rates. Moreover, from the perspective of the individual consumer, SMEs are particularly well suited to providing products and services that are relevant to the domestic context at reasonable prices. The SMEs allow for a fast turnover cycle lowering inventory costs, thus creating 
savings that can be passed on to the customer. It is also regularly argued that SMEs are a viable mechanism of increasing national exports. Thus, to enhance and support such sector, and to explore the foundation for the establishment and development of such firms within the Palestinian context, it is necessary to explore the various issues and aspects.Palestinian SMEs are the engine of the economy; these companies have a greater opportunity to grow when the environment encourages them so we have to look at them as an essential sector in the economy that create an effective system which involve all related parties.

According to the Palestinian Center for Statistics the total number of establishments operating in Palestine in 2007 was 132,874 enterprises 90.7 of them are a private ownership, the percentage of SMEs around 90\% of Palestinian enterprises (Mosallem, 2016).
In the recent years, there is a clear interest in SMEs among different sectors in Palestine such as; academic field, economic field and civil society institutions. Nevertheless, and as Sabri, (2016), showed in his study; there is no clear classification for SMEs in Palestine. Also, there is no accurate or reliable statistics about the number and the scope of SMEs in Palestine. In addition, a great portion of small firms are operating within informal sectors, so they are not registered officially and not counted in any statistical survey.

According to many studies and official reports from different developing countries it is clear that the most widely used criterion to define SMEs is the number of employees. Accordingly, and for statistical purposes, the Palestinian Centre Bureau of Statistics (PCBS, 2017a) uses the following classifications of enterprises, according to number of employees as shown in table 1 below.

\begin{tabular}{|c|c|c|c|c|}
\hline \multicolumn{5}{|c|}{ Definition According to Number of Employees } \\
\hline Indicator & $\begin{array}{c}\text { Micro } \\
\text { Enterprise }\end{array}$ & $\begin{array}{c}\text { Small } \\
\text { enterprises }\end{array}$ & $\begin{array}{c}\text { Medium } \\
\text { enterprises }\end{array}$ & $\begin{array}{c}\text { Large } \\
\text { enterprises }\end{array}$ \\
\hline Employees & $1-4$ & $5-19$ & $20-49$ & 50 or more \\
\hline
\end{tabular}

Table 1:- Classification of enterprises according to PCBS (source PCBS 2017).

Either in developed or developing countries like Palestine; the high importance of the number of employees as an indicator of defining SMEs comes from the ease of counting and measuring. Therefore, and based on the previous developed table; "SMEs are those enterprises that employ between 5 and 49 employees. Small enterprises are those employing between 5 and 19 employees whereas medium enterprises would be those employing between 20 and 49 employees". In a study conducted by (Mosallem, 2016) and the Palestinian Ministry of Economy it defines small enterprises as projects that have 6-15 workers and the capital that invested in fixed assets is less than $\$ 15,000$. The medium is a project that employs $15-50$ workers and invests from $\$ 15000$ to $\$ 25000$ in fixed assets (Issam, 2010). According to the PMA SMEs are firms staffed by less than 25 employees, their annual sales not exceeding seven million dollars or equivalent (Mosallem, 2016).

In emerging economies, Small and Medium sized Enterprises (SMEs) contribute greatly to growth and development. Compared to larger commercial enterprises, SMEs have a number of unique attributes. SMEs are smaller and consequently more flexible. This makes SMEs able to adapt their operations to market changes and to respond to new demands with greater ease and innovation. Due to the importance of SMEs to domestic economies and to the global economy in general, interest in the various dimensions of small-scale commercial activity is increasing in both academic and policy-making circles alike (Issam, 2010). Comparing SMEs and large-scale enterprises is a regular subject of debate amongst scholars of economic development. The most common debates are in regards to the advantages and disadvantages of small-scale entrepreneurship, including business size, number of employees, invested capital and the value and frequency of transactions. The benefits of small-scale entrepreneurial ventures are determined by a number of macro and micro level factors that include the size of the national economy, the prevailing legislative framework, employment opportunities for skilled and unskilled labor, production costs, potential economies of scale, legislation regarding ownership, rates of return on investments, the culture of corporate socialresponsibility.

In many ways, Palestinian SMEs constitute the Palestinian economy. According to the Palestinian Central Bureau of Statistics PCBS, SMEs comprised 99\% of all businesses in 1998. In the past, studies have been conducted in order to assess the advantages of SMEs compared to larger-scale corporate ventures within the Palestinian context. In general, these studies have indicated that SMEs have a number of specific advantages and, for this reason, should be encouraged through policy initiatives (Sabri, 2016). Previous studies have found that smaller firms have higher average rates of labor productivity and a higher ratio of assets and inventory turnover than largescale industries, despite the fact that larger firms have greater access to external financing. According to Mosallem (2016), nearly all studies have emphasized the importance of SMEs and their active role in economy as they accounted for more than $90 \%$ from all enterprises in most countries which mean that any hit or recovery in this sector will reflect on the economy.

\section{B. Mobile Banking in Palestine}

In Palestine, the banking sector which still evolving is managed by Palestinian Monetary Authority (PMA), according to Palestine Monetary Authority (2019), report there are 14 banks commercial banks in West Bank and Gaza with 351 branches and delegate offices, Seven of 
them are local (two Islamic banks) and seven of them are foreign banks (six Jordanian and one Egyptian bank). The banking infrastructure is fairly well developed, with some villages having bank offices, which are mini branches provides most services needed by low income clients, including withdrawal of deposits and deposit taking, and money transfers etc. There are currently a total of 161 bank branches, offices, and cash offices (a banking outlet where a more limited number of services may be provided) across Palestine, and the Palestine Monetary Authority (PMA) is strongly encouraging banks to open more branches and offices (Grossman, 2008). Moreover, the use of mobile phones for services other than send and receive calls, highly improves the labor productivity of service firms in Palestine (Morrar, et al. 2019).

\section{Contribution of SMEs to Palestine Economy}

SMEs contribution in Palestinian economic sectors shows that wholesale, retail and repairs represent $51.1 \%$, followed by the manufacturing $12.4 \%$, services activities come in the third place by $11.1 \%$, then the food sector accounted for $4.8 \%$, health activities $4.0 \%$, education activities 3.9 , and the rest is distributed to other sectors (PCBS, 2017 \& Mosallem, 2016). SMEs are critical for achieving the aforementioned policy objectives. It shows that, despite their limited share of total establishments, these enterprises have a strong presence in the surveyed sectors and stand as a major source of employment and production growth (UNCTAD, 2004). Based on the United Nation report, SMEs in Palestine shows a contribute to industrial growth, also to the construction growth as well as the tourism growth.

\section{Information and Communication Technology (ICT) in Palestine}

Over the last few decades, there has been an increase in the development of computing and telecommunication technologies, which has enabled, in a significant way, the development of an advanced global business and commerce (Mohammed, et al. 2020). Information and Communication Technology (ICT) is a vital engine for economic growth in developed economies (Morrar, et, al. 2019). SMEs have started using ICT relatively recently and they are generally characterized by inferior technology and management capabilities (Harindranath, et al. 2008). Information and Communication Technology is one of the fastest growing sectors in the Palestinian Territory, mainly thanks to private telecommunications services, the growth rate of this sector has averaged $25-30 \%$ annually since 2000 (Telecommunication \& Commerce, 2016; Amer, 2010), ICT are identified as the tools, systems, operations, and processes that are concerned with the various kinds of data processing for the sake of extracting useful or meaningful information out of them to be used by people and institutions to achieve development (Amer, 2010). It is widely believed that ICT is a powerful enabler of economic development, The ICT sector started in Palestine in the early 1980s with few hardware re-sealers working as sub-dealers to the Israeli agents. By mid 1980s, some software development emerged providing accounting and word processing solution to end users in the local market, the beginning of the 1990s brought further growth for the ICT sector in Palestine as a new businesses emerged and started to develop and provide additional software products and services such as internet services, and customized solutions in order to meet the demand coming from the private sector, government, universities, municipalities. By the late of 1993 and 1994 when the Oslo agreement was signed and the Palestinian Authority was established, additional demand for ICT hardware and solutions by the government continued to contribute to the growth of ICT market in Palestine, by end of 1995, the ICT sector started to show significate growth responding to the increased demand coming from the central and local government, colleges, universities, private sector and non-government organizations (NGO's), The Palestinian ICT sector has registered impressive growth over the last few years, on the end of 2013 the ICT sector in Palestine reach of $\$ 637 \mathrm{M}$ and $6 \%$ of GDP with Telecom make up to $70 \%$ and IT up to $30 \%$ of the sector revenues. (Office of the Quartet Representative, 2014), However, the sector in small but growing rapidly.

In the telecommunication in Palestine, there is 2 mobile communications companies (Jawwal 80\% and Wataniya $20 \%$ of the market share), and 1 fixed communication company (Paltel), with 11 ISPs and 77\% penetration for voice and SMS services, and a low data penetration ( $2 \mathrm{~g}$, WIFI and recently newly coming $3 \mathrm{~g}$ ) representing $11 \%$ of mobile revenues, Israeli operators captures 20 to $40 \%$ of the market share, the telecommunication has a restrictions on access to spectrum and to import and installation of equipment, in addition, high quality broadband fixed line network is developed for large businesses. While the IT sector in Palestine growth has been driven by international partnerships, including Cisco, Intel and google. A report by the Palestinian Central Bureau of Statistics (PCBS, 2017), the report mentioned that the ongoing developing of ICT and adopting it in the Palestinian economy has led to an increase in the number of people who use computers to reach $63.1 \%$ of the entire population of Palestine in the year 2014 (Herzallah, 2018).

The Palestinian ICT sector is getting more and more recognition from both within the Palestine and around the rest of the world. For a small economy with a young and well-educated population, the ICT sector has the potential to make a strong contribution to balanced sustainable growth. In recent years there has been an increase in the number of companies, as well as inward investment from international names such as Cisco and Intel. This special feature documents this growth, and considers what factors might need to be addressed to help the sector deliver its potential (Trust, 2012). In the Palestinian case, ICT has also a special role to play in making up the blockades and barriers imposed on Palestinians by the Israeli authorities, without which communication with the outside world would be impossible, and extremely difficult to synchronize activities and cooperate (Amer, 2010). The world ranking of Palestine is 62 nd in terms of Facebook users with $37 \%$ of the population using the social networking site. For comparison, Lebanon and Jordan are ranked 69th and 68th with rates of $35 \%$ and $35 \%$ respectively. Access to 
information (85.7\%), entertainment $(79.3 \%)$ and communication $(69.1 \%)$ are the main reasons for the use of internet in Palestine, followed by studying (49.3\%) and work $(18.2 \%)$. These figures show that although computers and the internet have widely penetrated households, most job positions still do not require their use (Trust, 2012).

Before the creation of the PNA, telecommunications infrastructure and services in the Palestinian territories were in a very poor state, due to underinvestment, neglect, and Israeli restrictions. Since the mid-nineties, hence, the ICT sector has developed rapidly. The Palestine Telecommunications Company (PALTEL) was established in 1995 and Pal-Cell (Jawwal) was set up in 2005 to provide mobile phone services. In 2008, the number of telephone lines was approximately 357,509. Meanwhile, Jawwal counted 1,400,000 subscribers by 2008 (Amer, 2010) also the department of economics stated that the Palestinian ICT sector has strengths in terms of competitive labor cost and positive sector growth rates despite the political situation. The Palestinian private sector, as well as consumers, responds quickly to technological offerings. The size of the Palestinian ICT market is a modest one compared to neighboring countries. hence, it has been growing steadily for the past 10 years. Estimates of the ICT market was at a value of about US\$120 million in 2000, then it dropped to US\$87 million in 2003 only to rebound in 2007 to US\$ 250 million.

\section{E. The Role of Mobile Banking in SMEs}

Mobile banking is simply the use of a phone or application to get the banking services at any time anywhere, some of the banks in Palestine has adopt the mobile banking technology. I notice that there are no studies have taken into consideration the factors influence or affect the intention to adopt or implement mobile banking in Palestine SMEs or even in the Palestinian organizations in both private and public sectors. Various empirical studies indicate SMEs are influenced by various factors when adopting a particular type of technology (Yeboah-boateng and Essandoh, 2014). The use of mobile phones in Palestine is widespread and reaches into the lower-income deciles, with $81 \%$ of households having access to a mobile phone as of 2006 (Grossman, 2008). However, the adoption of mobile banking in Palestine SMEs is still lower than expected, many barriers to mobile adoptions and other ICT application in SMEs have been identified in Palestine, such as the shortage of resources such as expertise and financial, lack of skills, lack of knowledge about the potential of mobile banking and other IT applications. a lot of studies show that the environmental factors like government interventions, public administrations, external pressure from other competitors, organizational factors, like suppliers and buyers, management support play an important role in adoption and implementation of ICT like mobile banking in Palestine specially in SMEs.
In Palestine the understanding of mobile banking adoption is very little among the SMEs business owners, and in the present knowledge-based economy, it is important for SMEs to adopt processes that enable them to provide services that will bring about competitive advantage (Rahman and Ict, 2018). ICT has a significant positive impact on organizational performance (Maldeni and Jayasena, 2009) and is vital to SMEs. The Palestinian SMEs could use mobile banking in order to grow and become more innovative, in addition there is a need to encourage the use of mobile banking and other ICT applications use in the Palestinian SMEs and address the high importance of implementation of the mobile banking by the right ways to improve the technical and managerial skills and making available e-business solutions for SMEs in Palestine, moreover the use of mobile banking will offer many benefits to SMEs at different levels (Rahman and Ict, 2018).

In Palestine, small and medium size enterprises are benefiting from the use of mobiles in the same as large enterprises (Rabayah and Qalalwi, 2011), especially in customer services and marketing. But in the same time, the use of mobile banking is very recent and little comparing to other developed countries, and our neighbor country Israel, the Palestinian SMEs can benefit from using mobile banking by two ways, first by being producers of mobile banking applications and second the Palestinian SMEs can be users of mobile banking with the intention to improve communication for reaching new client's or to increase productivity.

The use of mobile banking in Palestinian SMEs would help change the way of their businesses operation in this area of globalization by changing business structures, and by creating competitive advantage and increasing competition for businesses, and by changing business operations, for that say, the SMEs in Palestine must have an ability to compete and dynamically respond to rapidly changing markets using mobile banking and other ICT applications. If the Palestinian SMEs want to stay and survive in a competitive international economy it is important to use new ICT such as mobile banking, to gain competitive advantage and for stability in global markets. There are some barriers to adopt mobile banking and other ICT application in Palestine SMEs, in general, mobile banking adoption will be based on the culture and the firm type, the lack of applicability to the business preferences for established business models, un-suitability for the business type, enabling factors such as qualified personnel, availability of ICT skills, network infrastructure, cost factors such as ICT networks and equipment, organization security and software, and trust factors which includes reliability and security of ICT systems, uncertainty of payment methods, intellectual property right also the legal framework and challenges in areas of technological capabilities productivity and management skills, and competitiveness really hinder the adoption of mobile banking by SMEs in Palestine. 
Since most of the SMEs in Palestine are family business, so the managers or owners of SMEs are the decision makers for their companies, and for that matter taking decisions in adopting mobile banking becomes quite a challenge as a result of lack of awareness of the benefits of the adoption and implementation in making up the decision. Also lack of knowledge on the perceived benefits and how to use the technology is a key factor that the owners or managers lack to take up to mobile banking.

In previous studies, lin (2006) identified that organizational size, CEO's characteristics and management perception of relative advantage, complexity and compatibility are the determinants influencing the adoption of ICT in SMEs. Regarding Seyal et al. (2007) study, the finding is that the significant predictors influencing SMEs in Brunei to adopt ICT are the management support and government support. there are some studies found that there is a relationship between ICT skills and ICT adoption, Shiels et al. (2003) asserted that stronger ICT capability including the specific ICT skills of SMEs owners has a significant influence on adoption of ICT. Ndubisi and Jantan (2003), found that computing skills and technical backing are strong factors of the perception of usefulness and also wield direct influence on system uses are the evaluating information system among SMEs companies in Malaysia. Wainwright et al. (2005) says that ICT knowledge, ICT skills and ICT practices are important factors and determinants of whether ICT is rejected or adopted by SMEs. Seyal \& Abdrahman (2003), study shows that among
SMEs business organizations of different types, they found that the major factors and determinants of e-commerce adoption are adoption attributes such as compatibility, relative advantages, trainability, observability, and organizational attributes such as size, nature, and type of business.

\section{MATERIAL AND METHODS}

There are different factors behind the low utilizations of mobile banking among SMEs in Palestine, these factors identified below based on a survey that was conducted between 1st of October 2019 and 31st of Jan 2020 in the biggest four governorates in Palestine. A total of 600 questionnaires were distributed among the small and medium enterprises around Palestine with usable response of 408 questionnaires, with an indicating response rate $68 \%$.

\section{RESULTS AND DISCUSSION}

This section provides results and discussion on the findings from the data gathered from the survey. The results give a general picture on the SMEs from a different sector's, with a general view on their usage of ICT in general and mobile banking in particular. However, some factors where consider by respondents as a major factors inhibiting the effective utilizations of mobile banking among SMEs in Palestine. see below table 2.

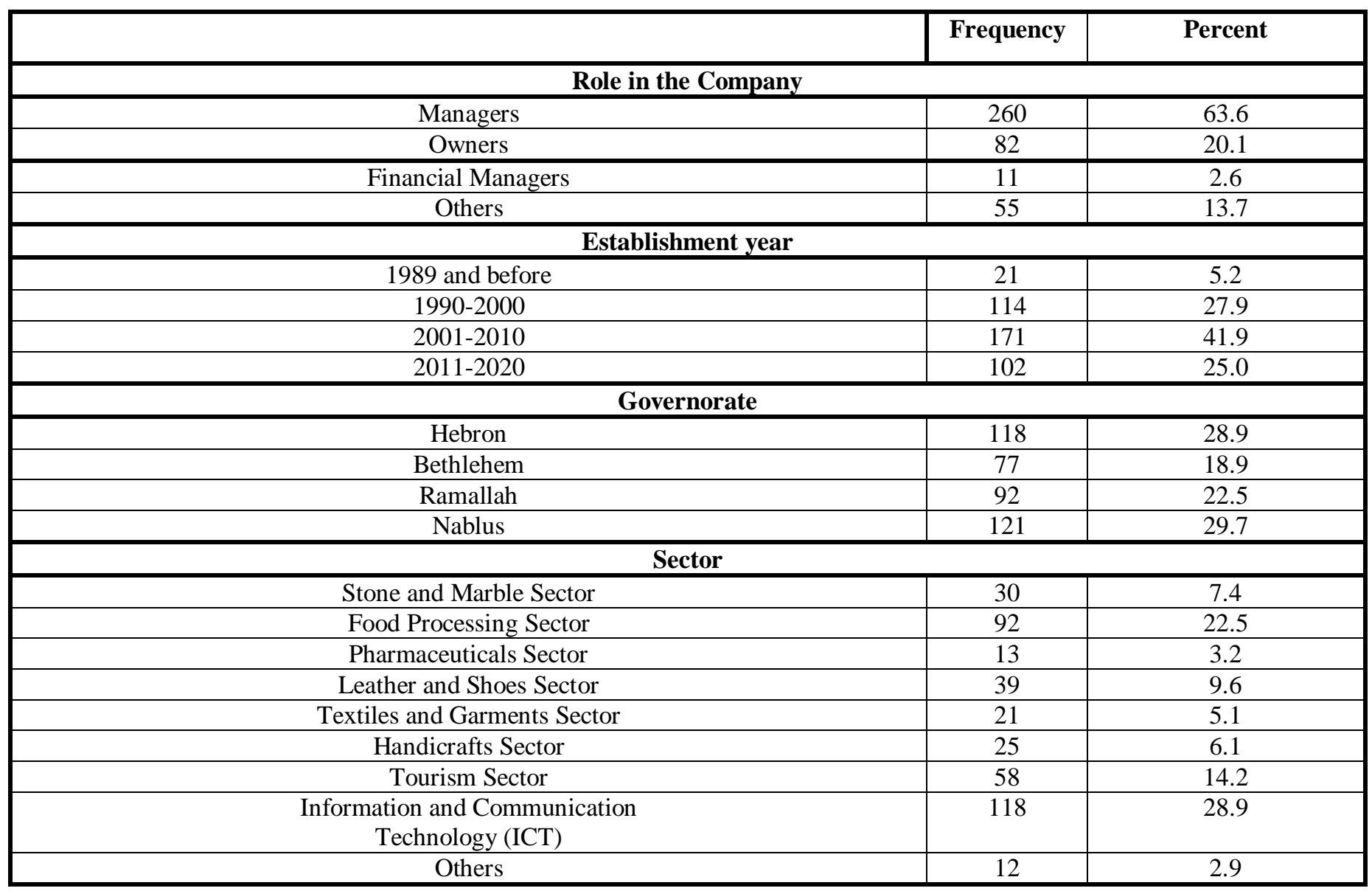


ISSN No:-2456-2165

\begin{tabular}{|c|c|c|}
\hline \multicolumn{3}{|c|}{ Active Client } \\
\hline 2,000 and below & 397 & 97.3 \\
\hline 2001 to 5000 & 6 & 1.4 \\
\hline 5001 to 10,000 & 1 & 0.2 \\
\hline More than 10,000 & 4 & 0.9 \\
\hline \multicolumn{3}{|c|}{ Number of employees } \\
\hline Less than 50 & 226 & 55.4 \\
\hline $50-200$ & 144 & 35.3 \\
\hline More than 200 & 38 & 9.3 \\
\hline \multicolumn{3}{|c|}{ Type of (Product / Services) offered } \\
\hline Products & 137 & 33.6 \\
\hline Services & 114 & 27.9 \\
\hline Both & 157 & 38.5 \\
\hline \multicolumn{3}{|c|}{ Type of Market } \\
\hline local & 202 & 49.5 \\
\hline Export & 18 & 4.4 \\
\hline Both & 188 & 46.1 \\
\hline \multicolumn{3}{|c|}{ Using of Computerized System } \\
\hline Yes & 365 & 89.5 \\
\hline No & 43 & 10.5 \\
\hline \multicolumn{3}{|c|}{ Total Number of Computers } \\
\hline $0-50$ & 367 & 90.0 \\
\hline $51-100$ & 31 & 7.5 \\
\hline More than 100 & 10 & 2.5 \\
\hline \multicolumn{3}{|c|}{ Using of Computers } \\
\hline Less than 3 years & 44 & 10.8 \\
\hline $3-5$ Years & 87 & 21.3 \\
\hline More than 5 years & 277 & 67.9 \\
\hline \multicolumn{3}{|c|}{ ICT Budget } \\
\hline Less than $10 \%$ & 322 & $79.0 \%$ \\
\hline 10 to $20 \%$ & 42 & $10.7 \%$ \\
\hline More than $20 \%$ & 44 & $10.3 \%$ \\
\hline \multicolumn{3}{|c|}{ Website Availability } \\
\hline Yes & 364 & 89.2 \\
\hline No & 44 & 10.8 \\
\hline \multicolumn{3}{|c|}{ Main use of the Website } \\
\hline Customer log in & 1 & .2 \\
\hline Marketing & 246 & 60.3 \\
\hline No & 23 & 5.6 \\
\hline Sales & 41 & 10.0 \\
\hline Status & 53 & 13.0 \\
\hline To provide information & 43 & 10.5 \\
\hline \multicolumn{3}{|c|}{$\begin{array}{c}\text { Provider of Mobile Banking } \\
\end{array}$} \\
\hline Yes & 93 & 22.8 \\
\hline No & 315 & 77.2 \\
\hline Total & 408 & 100.0 \\
\hline
\end{tabular}

Table 2:- Frequency and percent of respondents answers.

The majority of the respondents $63.6 \%$ were managers of the SMEs, while $20.1 \%$ were owners. While the rest of the respondents were playing different roles in the companies, such as financial managers, Sales managers, Marketing managers, partners, CEO and other roles. In addition, most of the companies have been in the business between 2001 to 2010 with a rate $41.9 \%, 27.9 \%$ of the companies has established their SMEs between 1990 and
2000, and 25.0\% establishment was between 2011 and 2020 , while only $5.2 \%$ of the respondent's companies are established before 1989. In addition, $29.9 \%$ of the small and medium enterprises companies situated in Nablus, and $28.9 \%$ are from Hebron, $22.5 \%$ of them from Ramallah, followed by $18.9 \%$ are located in Bethlehem. Most of the respondent's business are Information and Communication Technology (ICT) sector with $28.9 \%$, followed by the food 
processing sector $22.5 \%$, and then the Tourism sector come third with $14.2 \%$, and other sectors shows lesser percentage. most of responding SMEs have 2,000 and below active clients $97.3 \%$, and only $0.9 \%$ has more than 10,000 active clients and they are the telecom companies. Also, 55.4\% of responding SMEs had under 50 employees, and $35.3 \%$ of the companies had employees of 50 to 200 , and only $9.3 \%$ had more than 200 employees. The majority of the respondents $49.5 \%$ were target the local market, while $46.1 \%$ were target both local and export market, followed by $4.4 \%$ only targeting only the export market. It should be recalled that $89.5 \%$ of SMEs use computerized systems in operation and $10.5 \%$ are not using computerized system. In addition, there are 367 SMEs have (0-50) computers and 31 SMEs have (51-100), and 10 SMEs only have more than 100 computers. In terms of experience of using computers, the result found that $67.9 \%$ of SMEs have over than 5 years' involvement with computers, $21.3 \%$ have between 3-5 years' involvement with computers, and the rest $10.8 \%$ have under 3 years of involvement with computers. Looking into the percentage of the ICT budget SMEs in Palestine spend in their organization, majority are having less than $10 \%$ budget $79.0 \%$, while $10.7 \%$ are having more than $20 \%$ budget for ICT, followed by $10.3 \%$ are having between 10 to $20 \%$ ICT budget in their organization. In response to products roll out by SMEs, majority $54.4 \%$ said that they first roll out is Management Information System, followed by Cashless Payment Systems 24.5\%, Artificial Intelligence and Ma 15.2\%, and mobile based commerce $4.2 \%$, last computers and nonusers of any system are $1.7 \%$. Majority $89.2 \%$ have a website page, $60 \%$ of them use the website for marketing, $10.5 \%$ use web to provide information, and $10 \%$ use the website page for sales purposes, while $13 \%$ use it to provide status. illustrates the distribution Does your company provide MB sample based on demography such as: Yes equal $22.8 \%$, whereas no equal $77.2 \%$. The results reveals that understanding of mobile banking adoption is very little among the SMEs business owner's, regulatory environment, mobile banking business model offered by banks are the most prevalent factors for non- utilizations of mobile banking.

\section{CONCLUSION}

In this FinTech era, SMEs in Palestine need to adopt mobile banking as early as possible, understanding the importance of this technology and its impact to their organizations and to their customer satisfaction is also important. And the readiness level for mobile banking adoption is below $30 \%$, which confirms there is a need to enhance the awareness level on the benefits of mobile banking and its impact to SMEs efficiency to understanding the unmet needs of a digital customers in a better way. SMEs in Palestine is not using mobile banking by effective way while they are using other ICT technologies more than mobile banking, SMEs in Palestine have a good infrastructure to adopt and implement mobile banking. The result of the survey reveals that understanding of mobile banking adoption is very little among the SMEs business owner's, regulatory environment, mobile banking business model offered by banks are the most prevalent factors for non-utilizations of mobile banking among SMEs in Palestine. Hence, efforts need to be made to enhance the awareness and the understanding of mobile banking among the private sector in general and SMEs in particular in Palestine.

The growing expectation from banks and SMEs customers is to meet their needs, and offer them a real time and easy use products and services, mobile banking would be a great shift in their products or services offered to their customers. There should be a right and great blend of acquisitions between the SMEs stakeholders, government in Palestine, the mobile network operators and the banks to come out with a great model of mobile banking to facilitate the SMEs operations, meet their customers' needs and have a safe model protected by good rules and finally to come out with an innovative solution for all parties and shift the traditional banking in Palestine (and the way SMEs work) to be more innovative. This would also open doors to banks in Palestine to be more competitive by offering exclusive services like mobile banking which would help them reaching more customers in new markets and even a new customer base.

Based on the study analysis, the researcher recommends banks in Palestine to educate the SMEs on mobile banking technology, and the way it works, and what services it could offer to their clients. decision makers have to pay attention to the importance of using such technology among the private sector, mobile network operators should design a model with banks to have a simple and easy use of mobile banking to facilitate the financial transactions by SMEs customers, not to forget that mobile banking model should be designed in safe system to have a big reliability by SMEs customers. Also results affirmed that mobile banking anticipated numerous benefits and advantages that will motivate the SMEs to adopt and implement mobile banking technology and mobile banking promises to increase the efficiency and outreach of SMEs in Palestine.

Finally, the Palestine Monetary Authority (PMA) need to develop policies that are geared towards addressing the issues affecting SMEs from effectively utilizing mobile banking, also gaining the benefits associated with mobile banking utilization.

\section{REFERENCES}

[1]. Abdalla, S. (2012). AN E-GOVERNMENT ADOPTION FRAMEWORK FOR DEVELOPING COUNTRIES: A CASE STUDY FROM SUDAN. 66(February), 37-39.

[2]. Ahad, T. (2014). INVESTIGATING A FRAMEWORK FOR PROVIDING MOBILE BANKING OPPORTUNITIES TO RURAL SMES IN BANGLADESH.

[3]. Ahuja, R., Sawhney, A., Jain, M., Arif, M., \& Rakshit, S. (2020). Factors influencing BIM adoption in emerging markets - the case of India. International Journal of Construction Management, 
20(1), $65-76$. https://doi.org/10.1080/15623599.2018.1462445

[4]. Al-Alawi, A. I., \& Al-Ali, F. M. (2015). Factors affecting e-commerce adoption in SMEs in the GCC: An empirical study of Kuwait. Research Journal of Information Technology, 7(1), 1-21. https://doi.org/10.3923/rjit.2015.1.21

[5]. Al-Isma'Ili, S., Li, M., Shen, J., \& He, Q. (2016). Cloud computing adoption determinants: An analysis of Australian SMEs. Pacific Asia Conference on Information Systems, PACIS 2016 Proceedings, 1-17.

[6]. Al-Qeisi, K. (2009). Analyzing the Use of UTAUT Model in Explaining an Online Behaviour: Internet Banking Adoption.

[7]. Al-Qeisi, K. I., \& Al-Abdallah, G. M. (2013). Internet Banking Adoption in Jordan: A Behavioral Approach.

[8]. International Journal of Marketing Studies, 5(6), 84-108. https://doi.org/10.5539/ijms.v5n6p84

[9]. Alam, S. S., \& Mohammad Noor, M. K. (2009). ICT Adoption in Small and Medium Enterprises: an Empirical Evidence of Service Sectors in Malaysia. International Journal of Business and Management, $4(2)$, $112-125$ https://doi.org/10.5539/ijbm.v4n2p112

[10]. Alismaili, S. Z., Li, M., Shen, J., Huang, P., He, Q., \& Zhan, W. (2020). Organisational-level assessment of cloud computing adoption: Evidence from the Australian SMEs. Journal of Global Information Management, 28(2), 73-89. https://doi.org/10.4018/JGIM.2020040104

[11]. Alizé Aversano, Sophie Evers, Amir Latif, M. V.-V. (2013). Mobile Telephony in Developing Countries : Mobile Telephony in Developing Countries :

[12]. Alrousan, M. K., Al-Adwan, A. S., Al-Madadha, A., \& Al Khasawneh, M. H. (2020). Factors Affecting the Adoption of E-Marketing by Decision Makers in SMEs. International Journal of E-Business Research, 16(1), 1-27. https://doi.org/10.4018/ijebr.2020010101

[13]. Alshamaila, Y., Papagiannidis, S., \& Li, F. (2013). Cloud computing adoption by SMEs in the north east of England: A multi-perspective framework. Journal of Enterprise Information Management, 26(3), $250-275$. https://doi.org/10.1108/17410391311325225

[14]. Alshamaileh, Y. Y. (2013). AN EMPIRICAL INVESTIGATION OF FACTORS AFFECTING CLOUD COMPUTING ADOPTION AMONG SMEs IN THE NORTH EAST OF ENGLAND. Phd Thesis.

[15]. Altameem, T. A. (2007). The Critical Factors of EGovernment Adoption An Empirical Study in the Saudi Arabia Public Sectors by Torki Abdulaziz Altameem. Brunel University, PhD(March).

[16]. Amini, M. (2014). THE FACTORS THAT INFLUENCE ON ADOPTION OF CLOUD COMPUTING FOR CONFIDENTIAL RESTRICTED ii "I hereby declare that I have read this dissertation and in my opinion this dissertation is sufficient in terms of scope and quality for the award of the degree of M. (January), 173.

[17]. Ammar, A., \& Ahmed, E. M. (2016a). Factors influencing Sudanese microfinance intention to adopt mobile banking. Cogent Business and Management, https://doi.org/10.1080/23311975.2016.1154257

[18]. Ammar, A., \& Ahmed, E. M. (2016b). Factors influencing Sudanese microfinance intention to adopt mobile banking. Cogent Business and Management, $3(1)$. https://doi.org/10.1080/23311975.2016.1154257

[19]. Ammar, A., \& Ahmed, E. M. (2016c). Factors influencing Sudanese microfinance intention to adopt mobile banking. Cogent Business \& Management, 5(1), 1-20. https://doi.org/10.1080/23311975.2016.1154257

[20]. Apulu, I., \& O. Ige, E. (2011). Are Nigeria SMEs Effectively Utilizing ICT? International Journal of Business and Management, 6(6), 207-214. https://doi.org/10.5539/ijbm.v6n6p207

[21]. Ardic, O. P., Mylenko, N., \& Saltane, V. (2011). Small and Medium Enterprises A Cross-Country Analysis with a New Data Set. In World Bank Policy Research Working Paper (Vol. 5538). https://doi.org/10.1596/1813-9450-5538

[22]. Awa, H. O., Ojiabo, O. U., \& Emecheta, B. C. (2015). Integrating TAM, TPB and TOE frameworks and expanding their characteristic constructs for e-commerce adoption by SMEs. Journal of Science and Technology Policy Management, 6(1), 76-94. https://doi.org/10.1108/JSTPM-04-2014-0012

[23]. Beck, T.H.L.: Pamuk, Haki; Uras, Burak; Ramrattan, R. (2015). MOBILE MONEY, TRADE CREDIT AND ECONOMIC DEVELOPMENT: THEORY AND EVIDENCE By Thorsten Beck , Haki Pamuk, Ravindra Ramrattan , Burak R . Uras This is also a European Banking Center Discussion Paper No . 2015-005 ISSN 2213-9532. Tilburg University, Center Dis.

[24]. Bett, F. C., \& Bogonko, J. B. (2017). Relationship between digital finance technologies and profitability of banking industry in Kenya. ... Academic Journal of Economics and Finance, 2(3), 34-56. Retrieved from http://www.iajournals.org/articles/iajef_v2_i3_34_5 6.pdf

[25]. Boonsiritomachai, W., \& Pitchayadejanant, K. (2017). Determinants affecting mobile banking adoption by generation $\mathrm{Y}$ based on the unified theory of acceptance and use of technology model modified by the technology acceptance model concept. Kasetsart Journal of Social Sciences, 40(2), 349-358. https://doi.org/10.1016/j.kjss.2017.10.005

[26]. CEDRIC AYVAN B. BILLOSO, MARK MARTIN C. CELINO, K. A. G. Y. (2014). DEMAND-SIDE ECONOMICS OF MOBILE MICROFINANCE: URBAN HOUSEHOLDS' WILLINGNESS TO PARTICIPATE, SOCIAL VALUE EXPECTATIONS AND PERCEPTION ON ITS 
EFFECTIVENESS IN ANGELES CITY, PHILIPPINES. Journal of Chemical Information and Modeling, 53(9), 1689-1699. https://doi.org/10.1017/CBO9781107415324.004

[27]. Chau, N. T., Deng, H., \& Tay, R. (2020). Critical determinants for mobile commerce adoption in Vietnamese small and medium-sized enterprises. Journal of Marketing Management, 00(00), 1-32. https://doi.org/10.1080/0267257x.2020.1719187

[28]. Chukwumah, S. (2017). Adoption of Mobile Banking Service in Rural Nigeria. 3(2), 76-78.

[29]. Claire. (2016). Consolidating Africa'S Mobile Banking Revolution. Global Economic Governance Programme, 1-44.

[30]. Creswell, J. W. (2014). Research Design.

[31]. Ege Oruç, Ö., \& Tatar, Ç. (2017). An investigation of factors that affect internet banking usage based on structural equation modeling. Computers in Human Behavior, 66, 232-235. https://doi.org/10.1016/j.chb.2016.09.059

[32]. Fall, F., Ky, Y., \& Birba, O. (2015). Analyzing the Mobile-Banking Adoption Process among LowIncome Populations : A Sequential Logit Model To cite this version : HAL Id : halshs-01225149 Volume 35 , Issue 4 Analyzing the Mobile-Banking Adoption Process among Low-Income Populations : A Sequen. 35(4), 2085-2013.

[33]. Giotopoulos, I., Kontolaimou, A., Korra, E., \& Tsakanikas, A. (2017). What drives ICT adoption by SMEs? Evidence from a large-scale survey in Greece. Journal of Business Research, 81(December 2016), 60-69. https://doi.org/10.1016/j.jbusres.2017.08.007

[34]. GOSAVI, A. A. (2015). ACCESS TO FINANCE FOR SMALL AND MEDIUM-SIZED FIRMS: EVIDENCE FROM EASTERN SUB-SAHARAN AFRICA. Submitted to Texas A\&M International University, 151(August), 10-17. https://doi.org/10.1145/3132847.3132886

[35]. Grossman, J. (2008). FIELD Report No . 6 Mobile Money Study : West Bank \& Gaza the FIELD Support LWA FIELD Report No . 6 Mobile Money Study : West Bank \& Gaza. (6).

[36]. GSMA. (2016). The Mobile Economy: Middle East and North Africa 2016. GSMA Intelligence, 1-70.

[37]. Gupta, S., Misra, S. C., Kock, N., \& Roubaud, D. (2018). Organizational, technological and extrinsic factors in the implementation of cloud ERP in SMEs. Journal of Organizational Change Management, $\quad 31(1)$, 83-102. https://doi.org/10.1108/JOCM-06-2017-0230

[38]. Harindranath, G., Dyerson, R., \& Barnes, D. (2008). ICT Adoption and Use in UK SMEs: a Failure of Initiatives? Electronic Journal of Information Systems Evaluation, 11(2), 91-96.

[39]. Hartarska, V., \& Nadolnyak, D. (2007). Do regulated microfinance institutions achieve better sustainability and outreach? Cross-country evidence. Applied Economics, 39(10), 1207-1222. https://doi.org/10.1080/00036840500461840
[40]. Hemlata Gangwar, Hema Date, R. R. (2015). Understanding determinants of cloud computing adoption using an integrated TAM-TOE model. (Unit 07), 1-5.

[41]. Herzallah, F. A. T. (2018). E-Commerce Adoption Factors Among Palestinian SMEs : A Descriptive Study. (September 2016).

[42]. Horus Development Finance. (2011). Study for the Establishment of Pro-Poor Branchless Banking in Sudan- Final Report. (January), 1-154.

[43]. Hossain, M. A., \& Ahmed, F. (2014). Evaluating the Impact of Mobile Banking Deployment for Microfinance. University of Dhaka Journal of Marketing, 2012(15), 144-157.

[44]. Hossain, S., \& Sarker, D. (2015). Benefits And Constraints of Using Mobile Banking In Microfinance In Developing Countries. 1(1).

[45]. Ifinedo, P. (2015). Internet/e-business technologies acceptance in Canada's SMEs: An exploratory investigation.

[46]. Jia, Q., Guo, Y., \& Barnes, S. J. (2017). Enterprise 2.0 post-adoption: Extending the information system continuance model based on the technologyOrganization-environment framework. Computers in Human Behavior, 67, 95-105. https://doi.org/10.1016/j.chb.2016.10.022

[47]. Joanthan Donner, M. E. (2010). Financial Inclusion and Development: A Cross Country Analysis. In Annual Conference of the Human Development and Capability Association, New Delhi, 168(10-13), 130. https://doi.org/10.1002/jid

[48]. K.Rabayah. (2013). Adoption Patterns of Information and Communication Technologies by enterprises in developing countries (Case Study Palestine). (December), 27. Retrieved from http://www.iimahd.ernet.in/egov/ifip/Khalid Rabayah.htm

[49]. Karrar, A. Z., \& Rahman, A. A. (2015). Mobile network operators' needs in collaborative mobile money service provision. ARPN Journal of Engineering and Applied Sciences, 10(23), 1784317852.

[50]. Katua, N. T. (2014). The Role of SMEs in Employment Creation and Economic Growth in Selected Countries. International Journal of Education and Research, 2(12), 461-472.

[51]. Khayer, A., Talukder, M. S., Bao, Y., \& Hossain, M. N. (2020). Cloud computing adoption and its impact on SMEs' performance for cloud supported operations: A dual-stage analytical approach. Technology in Society, 60, 101225. https://doi.org/10.1016/j.techsoc.2019.101225 Kisore, R. (2015). Study of Mobile Payment Solutions from Across the World. 1(1).

[52]. Kshetri, N., \& Acharya, S. (2012). Mobile payments in emerging markets. IT Professional, 14(4), 9-13. https://doi.org/10.1109/MITP.2012.82

[53]. Kumar, D., Samalia, H. V., \& Verma, P. (2017). Factors Influencing Cloud Computing Adoption by Small and Medium-Sized Enterprises (SMEs) In India. Pacific Asia Journal of the Association for 
Information Systems, 9(3), 25-48. https://doi.org/10.17705/1pais.09302

[54]. Kumlachew, M. (2015). Technology adoption of Ethiopian manufacturing firms: The case of textile and leather sector.

[55]. Lai, P. (2017). the Literature Review of Technology Adoption Models and Theories for the Novelty Technology. Journal of Information Systems and Technology Management, 14(1), 21-38. https://doi.org/10.4301/s1807-17752017000100002

[56]. Laukkanen, T. (2007). Internet vs mobile banking: Comparing customer value perceptions. Business Process Management Journal, 13(6), 788-797. https://doi.org/10.1108/14637150710834550

[57]. Luarn, P., \& Lin, H. H. (2005). Toward an understanding of the behavioral intention to use mobile banking. Computers in Human Behavior, 21(6), 873-891. https://doi.org/10.1016/j.chb.2004.03.003

[58]. MacGregor, R., \& Vrazalic, L. (2004). Electronic commerce adoption in Small to Medium Enterprises (SMEs). A Comparative Study of SMEs in Wollongong (Australia) and Karlstad (Sweden), University of Wollongong, (May).

[59]. Makena, J. N. (2013). Factors That Affect Cloud Computing Adoption By Small and Medium Enterprises in Kenya. International Journal of Computer Applications Technology and Research, 2(5), 517-521. https://doi.org/10.7753/ijcatr0205.1003

[60]. Mandari, H. E., Koloseni, D. N., \& Macha, J. (2019). Continuance Usage of Mobile Banking Services Among Small and Medium Enterprises (SMEs) in Tanzania. International Journal of ICT Research in Africa and the Middle East, 9(1), 50 66. https://doi.org/10.4018/ijictrame.2020010103

[61]. Mensah, I. K. (2019). Impact of Government Capacity and E-Government Performance on the Adoption of E-Government Services. International Journal of Public Administration, O(00), 1-9. https://doi.org/10.1080/01900692.2019.1628059

[62]. Mohammadi, A., Saeedikondori, A., \& Ali, and N. A. Bin. (2017). Factors Influencing Cloud Computing Adoption in. Journal of ICT, 1(1), 2141.

[63]. Mohammed, A.-M., Idris, B., Saridakis, G., \& Benson, V. (2020). Information and communication technologies: a curse or blessing for SMEs? In Emerging Cyber Threats and Cognitive Vulnerabilities. https://doi.org/10.1016/b978-0-12816203-3.00008-3

[64]. Morrar, R., Abdeljawad, I., Jabr, S., Kisa, A., \& Younis, M. Z. (2019). The role of information and communications technology (ICT) in enhancing service sector productivity in Palestine: An international perspective. Journal of Global Information Management, 27(1), 47-65. https://doi.org/10.4018/JGIM.2019010103

[65]. Mosallem, L. (2016). Banking sector role in the SMEs development in Palestine Table of content. Muchiri, J. W. (2018). Effect of Mobile Banking
Adoption on the Performance of Small and Medium Enterprises in Nairobi County. International Journal of Economics, Business and Management, 2(4), 445-486.

[66]. Muñoz-Leiva, F., Climent-Climent, S., \& LiébanaCabanillas, F. (2017). Determinantes de la intención de uso de las aplicaciones de banca para móviles: una extensión del modelo TAM clásico. Spanish Journal of Marketing - ESIC, 21(1), 25-38. https://doi.org/10.1016/j.sjme.2016.12.001

[67]. Mwela, T. R. (2014). INFORMATION AND COMMUNICATION TECHNOLOGY USAGE IN DEVELOPMENT OF MICROFINANCE INSTITUTIONS SERVICES IN PERI-URBAN AREAS TANZANIA : A CASE OF ILALA MUNICIPALITY IN DAR-ES-SALAAM CITY By Tomaides $R$. mwela A Dissertation Submitted in Partial Fulfillment of.

[68]. National SME Development Council. (2013). GUIDELINE FOR NEW SME DEFINITION. (October).

[69]. O.Otieno, E., \& M. Kahonge, A. (2014). Adoption of Mobile Payments in Kenyan Businesses: A case study of Small and Medium Enterprises (SME) in Kenya. International Journal of Computer Applications, 107(7), 5-12. https://doi.org/10.5120/18761-0041

[70]. Obwogi, M. V. G. D. J. (2017). Factors Affecting the Adoption of Mobile Banking by Deposit Taking Sacco's in Kenya. International Journal of Science and Research (IJSR), 6(10), 1256-1262. https://doi.org/10.21275/ART20177469

[71]. Ochola, P. (2015). An Empirical Study of Determinants of E-Commerce Adoption Amongst Micro, Small and Medium Enterprises (MSMEs) in Kenya. International Journal of Economics, Commerce and Management, United Kingdom, 3(12), 223-240. Retrieved from https://pdfs.semanticscholar.org/370c/37d835933c8 57ac763c2966388c12b3744ea.pdf

[72]. OECD. (2005). Small Businesses, Job creation and Growth: Facts, Obstacles and Best Practices. Small, $1-\quad 54 . \quad$ https://doi.org/10.1002/1098240X(200006)23:3<246::AID-NUR9>3.0.CO;2-H

[73]. Oliveira, T., Thomas, M., \& Espadanal, M. (2014). Assessing the determinants of cloud computing adoption: An analysis of the manufacturing and services sectors. Information and Management, $51(5)$, $497-510$. https://doi.org/10.1016/j.im.2014.03.006

[74]. Palestine Trade Center. (2010). Challenges Facing ICT in Palestine. Retrieved from https://www.google.com/url?sa=t\&rct=j\&q=\&esrc= $\mathrm{s} \&$ source $=$ web $\& \mathrm{~cd}=1 \& \mathrm{cad}=\mathrm{rja} \&$ uact $=8 \& \mathrm{ved}=0$ ahUKEwj2mrCdyOnNAhVF5CYKHTcwCWwQFg gcMAA\&url=http $\% 3 \mathrm{~A} \% 2 \mathrm{~F} \% 2 \mathrm{Fsiteresources}$. world ba

nk.org\%2FINTWESTBANKGAZA\%2FResources $\%$ FChallengesFacingICTPalestine.pdf\&usg=AFQj $\mathrm{CNH}$ dHkq3m $3 \mathrm{hcZ}$ 
[75]. Pan, M. J., \& Jang, W. Y. (2016). Determinants of the adoption of enterprise resource planning within the technology-organization-environment framework: Taiwan's communications industry. Journal of Computer Information Systems, 48(3), 94-102. https://doi.org/10.1080/08874417.2008.11646025

[76]. PCBS. (2017). Palestinian Central Bureau of Statistics - Palestine in Figures. 8(9), 1-58. https://doi.org/10.1017/CBO9781107415324.004

[77]. Qashou, A., \& Saleh, Y. (2018). E-marketing implementation in small and medium-sized restaurants in Palestine. Arab Economic and Business Journal, 13(2), 93-110. https://doi.org/10.1016/j.aebj.2018.07.001

[78]. Rabayah, K. S., \& Qalalwi, K. (2011). The Impact of Mobile Telephony on Developing Country Enterprises: A Palestinian Case Study. The Electronic Journal of Information Systems in Developing Countries, 46(1), 1-20. https://doi.org/10.1002/j.1681-4835.2011.tb00326.x

[79]. Raharja, P. S. J., \& Tresna, R. (2019). , Nobuyuki Kobayashi, Seiko Shirasaka, Makoto Ioki Adoption of Information and Communication Technology on Enhancing Business Performance: Study on Creative .... Review of Integrative Business and Economics Research, 8(3), 20-30. Retrieved from http://search.proquest.com/openview/d5a8e7d9fc05 d19523ea62a33956ff7d/1?pqorigsite $=$ gscholar $\&$ cbl $=2032316$

[80]. Rahayu, R., \& Day, J. (2015). Determinant Factors of E-commerce Adoption by SMEs in Developing Country: Evidence from Indonesia. Procedia Social and Behavioral Sciences, 195, 142-150. https://doi.org/10.1016/j.sbspro.2015.06.423

[81]. Rahman, A.-, \& Ict, R. (2018). ICT Adoption Level in SMEs. (2018), 2017-2018.

[82]. Ramdani, B., Chevers, D., \& Williams, D. A. (2013). SMEs' adoption of enterprise applications: A technology-organisation-environment model. Journal of Small Business and Enterprise Development, 20(4), 735-753. https://doi.org/10.1108/JSBED-12-2011-0035

[83]. Ramdani, B., Kawalek, P., \& Lorenzo, O. (2009). Predicting SMEs' adoption of enterprise systems. Journal of Enterprise Information Management, 22, 10-24. https://doi.org/10.1108/17410390910922796

[84]. Ramdhony, D., \& Munien, S. (2013). An Investigation on Mobile Banking Adoption and Usage: A Case Study of Mauritius Ramdhony \& Munien. World Journal of Social Sciences, 3(3), 197-217.

[85]. Ros, S., Hernández, R., Caminero, A., Robles, A., Barbero, I., Maciá, A., \& Holgado, F. P. (2015). On the use of extended TAM to assess students' acceptance and intent to use third-generation learning management systems. British Journal of Educational Technology, 46(6), 1250-1271. https://doi.org/10.1111/bjet.12199
[86]. Sabri, N. R. (2016). Small Businesses and Entrepreneurs in Palestine. (October 2008). https://doi.org/10.2139/ssrn.1278057

[87]. SAFAVI, N. S. (2013). Re-Engineering Towards the Success of Enterprise Resource. (November).

[88]. Senarathna, I., Wilkin, C., Warren, M., Yeoh, W., \& Salzman, S. (2018). Factors that influence adoption of cloud computing: An empirical study of Australian SMEs. Australasian Journal of Information Systems, 22. https://doi.org/10.3127/ajis.v22i0.1603

[89]. Shaikh, A. A., \& Karjaluoto, H. (2015). Mobile banking adoption: A literature review. Telematics and Informatics, 32(1), 129-142. https://doi.org/10.1016/j.tele.2014.05.003

[90]. Sidek, N. (2015). Determinants of Electronic Payment Adoption in Malaysia : The Stakeholders ' Perspectives. https://doi.org/10.14264/uql.2015.696

[91]. Tambunan, T. T. H. (2011). Journal of Enterprising Communities: People and Places in the Global Economy. Global Economy Iss European Journal of Enterprising Communities : People and Places in the Global Economy, 9(2310), 94-113. https://doi.org/10.1108/17506201111119626

[92]. Torbiörnsson, A., \& Persson, J. (2013). Banking the Unbanked - The Case of Mobile Money in Nepal Banking the Unbanked - The Case of Mobile Money in Nepal Andreas Torbiörnsson. 1-100.

[93]. Van Huy, L., Rowe, F., Truex, D., \& Huynh, M. Q. (2012). An empirical study of determinants of ECommerce adoption in SMEs in Vietnam: An Economy in Transition. Journal of Global Information Management, 20(3), 23-54. https://doi.org/10.4018/jgim.2012070102

[94]. Venkatesh, V., \& Bala, H. (2008). Technology Acceptance Model 3 and a Research Agenda on Interventions Subject Areas: Design Characteristics, Interventions. Decision Sciences, 39(2), 273-315. Retrieved from http://www.vvenkatesh.com/wpcontent/uploads/2015/11/Venkatesh_Bala_DS_2008 .pdf

[95]. Venkatesh, V., \& Davis, F. D. (2000). Theoretical extension of the Technology Acceptance Model: Four longitudinal field studies. Management Science, $46(2), \quad 186-204$. https://doi.org/10.1287/mnsc.46.2.186.11926

[96]. Victoria Clarke, V. B. (2006). Using thematic analysis in psychology Using thematic analysis in psychology.

[97]. Psychiatric Quarterly, 0887(1), 37-41. https://doi.org/10.1111/j.1460-2466.1978.tb01621.x

[98]. Wangui, E. W. (2013). the Relationship Between Financial Inclusion and Economic Development in Kenya. University of Nairobi, (October), 81. https://doi.org/https://chss.uonbi.ac.ke/sites/default/f iles/chss/ELIZABETH\%20WANGUI\%20WAN GOO.pdf 
[99]. Wijesiri, M., Viganò, L., \& Meoli, M. (2015). Efficiency of microfinance institutions in Sri Lanka: A two- stage double bootstrap DEA approach. Economic Modelling, 47, 74-83. https://doi.org/10.1016/j.econmod.2015.02.016

[100]. Wisal Tingari \& Abadir Mahmoud. (2014). An empirical study evaluating the adoption of mobile banking in Sudan. Journal of Internet Banking and Commerce, 19(2).

[101]. Wu, W. Y., \& Ke, C. C. (2015). An online shopping behavior model integrating personality traits, perceived risk, and technology acceptance. Social Behavior and Personality, 43(1), 85-98. https://doi.org/10.2224/sbp.2015.43.1.85

[102]. Xena, P., \& Rahadi, R. A. (2019). Adoption of EPayment To Support Small Medium Enterprise Payment System: a Conceptualised Model. International Journal of Accounting, 4(18), 32-41. Retrieved from www.ijafb.com

[103]. Yeboah-boateng, E. O., \& Essandoh, K. A. (2014). Factors Influencing the Adoption of Cloud Computing by Small and Medium Enterprises in Developing Economies. (4), 13-20.

[104]. Yousif, F., Berthe, E., \& Morawczynski, O. (2011). Best Practices in Mobile Microfinance. 1-75. Zainol, N. F. (2011). Factors Influencing Mobile Banking Adoption Master of Science in Banking. 